\title{
Rinodina pyrina (Physciaceae, Ascomycota) new to Chile
}

\section{Rinodina pyrina (Physciaceae, Ascomycota) nueva especie para Chile}

\author{
Reinaldo Vargas Castillo ${ }^{1,2 *}$, Aissa Ibaceta ${ }^{1} \&$ Evelyn Vergara ${ }^{1}$ \\ ${ }^{1}$ Departamento de Biología, Universidad Metropolitana de Ciencias de la Educación, Avda. José Pedro Alessandri 744, Ñuñoa, \\ Santiago, Chile. \\ ${ }^{2}$ Departamento de Botánica, Universidad de Concepción, Casilla 160-D, Concepción, Chile. \\ *reinaldovargas@gmail.com
}

\begin{abstract}
RESUMEN
Rinodina pyrina (Ach.) Arnold es citada por primera vez para la micobiota liquenizada chilena. El material fue recolectado en el sector El Panul, en la precordillera de la ciudad de Santiago, Chile. La morfología, anatomía y química fueron revisadas y se entrega una descripción del material encontrado, su hábitat y distribución.
\end{abstract}

During a survey of the epiphyte lichens on Quillaja saponaria Molina in the surroundings of Santiago de Chile several specimens of Rinodina pyrina (Ach.) Arnold were found. This species is not listed in the checklist of lichens of Chile (Galloway \& Quilhot 1998) nor in any recent publication. The material was collected in El Panul Park, a private area with public access situated in the Cordillera Province, Metropolitan Region, between $32^{\circ} 55^{\prime}$ - $33^{\circ} 01^{\prime} \mathrm{S}$ and $71^{\circ} 09^{\prime}-71^{\circ} 01^{\prime} \mathrm{W}$, with altitudes ranging from 400 to $2,220 \mathrm{~m}$. It is one of the remaining areas in the proximity of Santiago de Chile that still presents sclerophyllous forest, and endemic vegetation formation, now replaced mainly by exotic plantations in Central Chile (Torres-Mura et al. 2008, Moreira-Muñoz 2011). There is no previous record of the lichen biota neither of the park nor in the surrounding areas. The aim of this work is to report the new record to the Chilean continental lichen biota and to present a description of the species, providing information on its possible distribution and habitat in Chile.

Morphological and anatomical observations were undertaken using light microscopy. Apothecial hand-cut sections were studied in water and $10 \% \mathrm{KOH}(\mathrm{K})$. Amyloid reactions in the hymenium, along with ascal observations, were tested with Lugol's iodine after a treatment with $10 \% \mathrm{KOH}(\mathrm{K} / \mathrm{I})$. Hymenia, ascospore and paraphyses were measured in $10 \% \mathrm{KOH}$. The material was observed under an Olympus SZ61 stereomicroscope coupled with a Lumenera Infinity 2 digital camera, and an Olympus $\mathrm{CH}$ (up to $\times 1000$ ) microscope. Secondary chemistry was studied using spot test and by means of TLC following Orange et al. (2001). The material collected is kept in the Botanical Collection Federico Johow of the Universidad Metropolitana de Ciencias de la Educación, Santiago de
Chile, with duplicates in the Botanical Collection of the Botany Department, Universidad de Concepción (CONC).

Rinodina pyrina (Ach.) Arnold, Flora 64: 196. 1881. Basionym: Lichen pyrinus Ach., Lich. Suec. Prod.: 52. 1799 [1798].

Lecanorapyrina (Ach.) Röhl.,Deutschl.Fl.,Abth.2(Frankfurt) 3: 72, 1813. Rinodina maculiformis (Hepp) Arnold, Flora 64: 196, 1881. Type: Sine loco, "Habitat in cortice ramorum Pyri communis \& Mali" (BM-ACH lectotype, Ropin \& Mayrhofer, Herzogia 9: 815, 1993 - not seen).

Thallus thin, up to $0.5 \mathrm{~cm}$ in diameter, discontinuous or effuse to rather thick and areolate, rarely rimose-areolate, sometimes forming small verrucae, especially at margins were it can be very dispersed and diffuse, pale whitish-grey to grey, rarely dark grey to brownish, epiphytic, without prothallus or vegetative propagules.

Apothecia 0.1-0.5 mm diam., scattered, numerous, subimmersed at first becoming lecanorine and sessile and broadly attached at maturity, disc plane, occasionally convex, brown to black, matt, somewhat scabrid, often confluent forming masses of 2-7 apothecia. Thalline margin concolorous with thallus, well-developed, thin, entire, persistent, sometimes crenulated, $40-90 \mu \mathrm{m}$ thick, usually with an epinecral layer of 2-10 $\mu \mathrm{m}$ thick. Proper margin hyaline, 5-20 $\mu \mathrm{m}$ wide. Epihymenium brown to darkbrown, $\mathrm{K}(-), 4-8 \mu \mathrm{m}$ thick. Hymenium hyaline, 50-70 $\mu \mathrm{m}$ tall. Paraphyses $1.5-2 \mu \mathrm{m}$ thick in the base, apices to $c a .4$ $\mu \mathrm{m}$ in diameter, 1-2 times branched. Hypothecium hyaline, 40-60 $\mu \mathrm{m}$ thick. Asci Lecanora-type, clavate, 30-55 × 11$16 \mu \mathrm{m}$, hyaline, 8-spored. Ascospores Physconia-type, spore ontogeny type A (sensu Mayrhofer \& Moberg 2002), 
immature spores elongated and somewhat curved, with faint median thickenings visible when fresh, walls thin, without distinct apical thickenings, pale- to dark-brown, smoothwalled, $(10-) 12-14(-16) \times 5-7(-8) \mu \mathrm{m}$, spore lumina with oil droplets in fresh specimens. Pycnidia immersed, hyaline, sometimes as a darkened spot in the upper surface of the areoles. Conidia hyaline, bacillar, 4-6 × 1-1.5 $\mu \mathrm{m}$ (Fig. 1).

Chemistry. No secondary compounds found. All spot test negative.

HABITAT AND Distribution. This corticolous species is very common and locally abundant in the studied area, on smooth bark of Quillaja saponaria and Lithrea caustica (Molina) Hook. \& Arn., particularly in young trees and twigs. Sometimes part of the thallus may grow directly on wood. Common accompanying species are Caloplaca clandestina Zahlbr., Candelaria concolor (Dicks.) Arnold, Chrysothrix granulosa G. Thor, Chrysothrix pavonii (Fr.) J.R. Laundon, Josefpoeltia sorediosa S.Y. Kondr. \& Kärnefelt, Lepraria incana (L.) Ach., Physcia adscendens H. Olivier, Ramalina chilena (Nyl.) Kashiw., Pyrenula nitida (Weigel) Ach., Teloschistes chrysophthalmus (L.) Norman ex Tuck., Xanthomendoza mendozae (Räsänen) S.Y. Kondr. \& Kärnefelt, Xanthoria adscendens S.Y. Kondr. and Xanthoria candelaria (L.) Th. Fr.

In Chile, Rinodina pyrina is known from the surroundings of Santiago de Chile, on the foothills of the Andes Cordillera in the sclerophyllous forest and it could potentially be present at the whole extent of this type of vegetation formation. The species is well known from temperate to boreal regions in the Northern Hemisphere, particularly in Europe (Ropin \& Mayrhofer 1993, Mayrhofer \& Moberg 2002), near Asia: Armenia (Harutyunyan \& Mayrhofer 2009, Harutyunyan et al. 2011), Cyprus, Syria and Turkey (Giralt \& Mayrhofer 1995), Central Asia: Tajikistan (Kudratov \& Mayrhofer 2002), Northern Africa (Magnusson 1947) and North America (Sheard 2004, 2010). It is also known from New Zealand (Wirth 1997; Mayrhofer et al. 2007), mainland Australia (Mayrhofer et al. 1999) and Tasmania (Kantvilas 1994, Mayrhofer et al. 1999) in the Southern Hemisphere.

Notes. Rinodina pyrina is characterized by its thin to evanescent grey to dark grey thallus, the abundant and crowded apothecia, and the small Physconia-type spores with almost excluded wall thickenings at the apices and reduced median thickenings. The species has been possibly overlooked in the continental Chilean territory given its small size and the inconspicuous crustose thallus and might be widespread in the central part of the country. It mainly occurs very abundantly on a variety of exotic trees and shrubs in Australia and New Zealand (Kantvilas 1994, Mayrhofer et al. 1999, 2007).

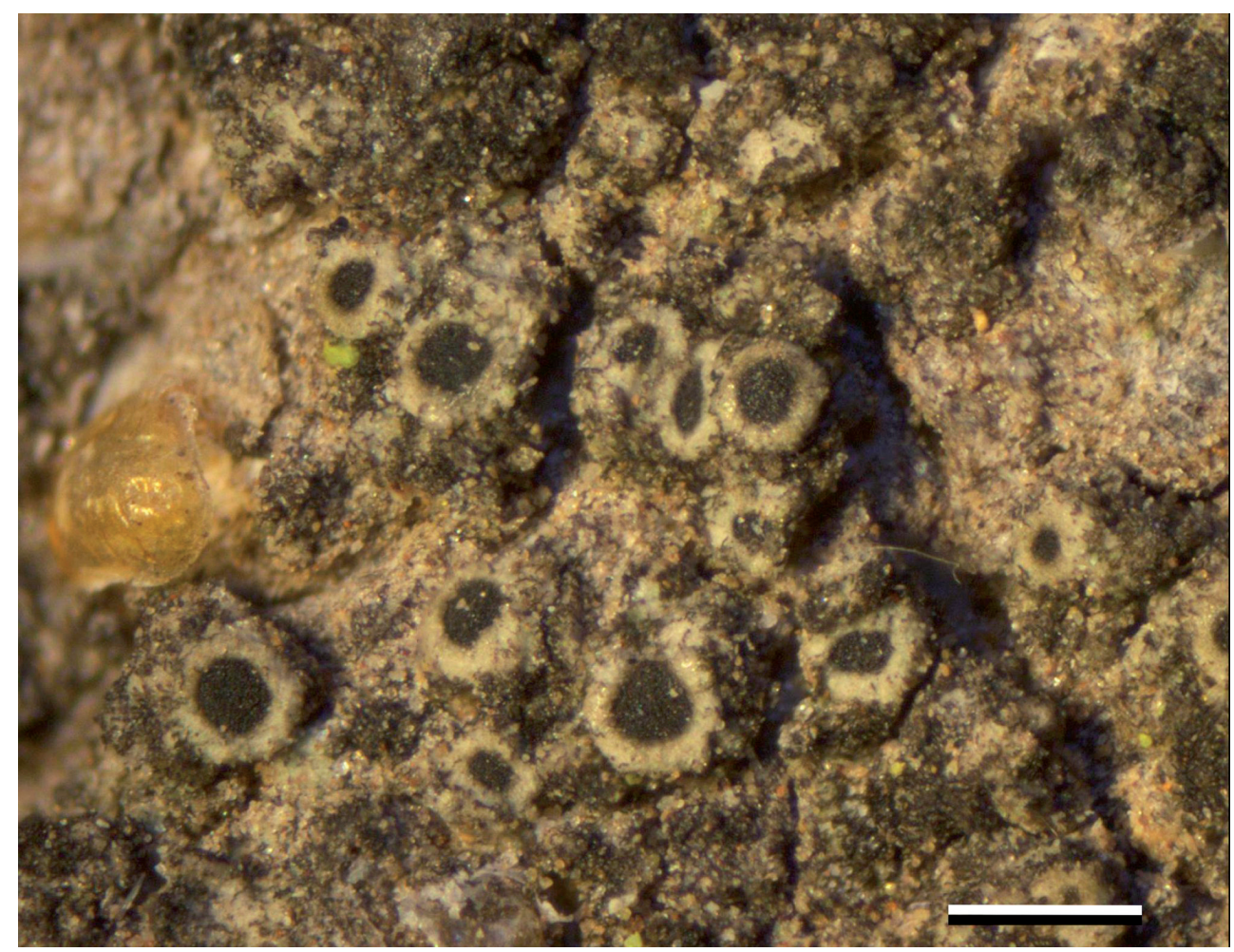

FIgURE 1. Rinodina pyrina, habit of the thallus, AI-EV 012 (CONC). Scale $=0.4 \mathrm{~mm}$.

FIGURA 1. Rinodina pyrina, hábito del talo, AI-EV 012 (CONC). Escala = 0,4 mm. 
Specimens eXamined: CHILE, Región Metropolitana, Prov. Cordillera, Comuna de La Florida, Sector El Panul, sobre corteza de Lithraea caustica, 33³2'06.2'S, 70³1'38.9' W +/- 3 m, 911 msnm, 05-V-2012, Vargas, Ibaceta \& Vergara, AI-EV 003, 004, 005 (UMCE, CONC); sobre corteza de

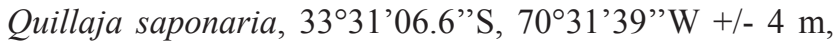
$902 \mathrm{msnm}, 05-\mathrm{V}-2012$, Vargas, Ibaceta \& Vergara, AI-EV 008 (UMCE, CONC); 3332'05.7'S, 70³1'39'”W +/- 3 m, $901 \mathrm{msnm}, 05-\mathrm{V}-2012$, Vargas, Ibaceta \& Vergara, AI-EV 009 (UMCE, CONC); 33³2'05.6”'S, 70³1'39.7' W +/- 4 m, 925 msnm, 05-V-2012, Vargas, Ibaceta \& Vergara, AI-EV 011 (UMCE, CONC); 3332'06”'S, 70³1'39.7' W +/- 4 m, $923 \mathrm{msnm}, 05-\mathrm{V}-2012$, Vargas, Ibaceta \& Vergara, AI-EV 012 (UMCE, CONC); 33³2'04.4'S, 70³1'41.6”'W +/- 4 m, 913 msnm, 05-V-2012, Vargas, Ibaceta \& Vergara, AI-EV 013 (UMCE, CONC); 3332'04.1'S, 70³1'41.7”'W +/- 4 m, 913 msnm, 05-V-2012, Vargas, Ibaceta \& Vergara, AI-EV 014 (UMCE, CONC); 3332'03.8”'S, 70³1'41.9”'W +/- 4 m, 912 msnm, 05-V-2012, Vargas, Ibaceta \& Vergara, AIEV 019 (UMCE, CONC); 3332'03.3”S, 70³1'42.9”'W +/- 4 m, 910 msnm, 05-V-2012, Vargas, Ibaceta \& Vergara, AI-EV 024, 025, 027 (UMCE, CONC); 3332'03.4”'S, 70³1'43.3” $\mathrm{W}+/-3 \mathrm{~m}, 909 \mathrm{msnm}, 05-\mathrm{V}-2012$, Vargas, Ibaceta \& Vergara, AI-EV 031 (UMCE, CONC).

\section{ACKNOWLEGMENTS}

This research was supported by a DIUMCE grant MYS II 04-2012 and a MECESUP grant UMC0204 to RV. Dr. H. Mayrhofer and an unknown reviewer are much appreciated for helpful comments on an earlier version of this manuscript. Dr. Ma. Catalina Sabando (UMCE) is thanked for providing imaging facilities.

\section{REFERENCES}

Galloway, D.J. \& W. Quilhot. 1998. Checklist of Chilean lichenforming and lichenicolous fungi. Gayana Botánica 55(2): 111-185.

Giralt, M. \& H. Mayrhofer. 1995. Some corticolous and lignicolous species of the genus Rinodina (lichenized ascomycetes, Physciaceae) lacking secondary lichen compounds and vegetative propagules in Southern Europe and adjacent regions. Bibliotheca Lichenologica 57: 127160 .
Harutyunyan, S. \& H. Mayrhofer. 2009. A contribution to the lichen mycota of Armenia. Bibliotheca Lichenologica 100: 137-156.

Harutyunyan, S., B. Wiesmar \& H. Mayrhofer. 2011. Catalogue of the lichenized fungi in Armenia. Herzogia 24: 265-296.

Kantvilas, G. 1994. A revised checklist of the Tasmanian lichen flora. Muelleria 8(2): 155-175.

Kudratov, I. \& H. Mayrhofer. 2002. Catalogue of the lichenized fungi of Tajikistan. Herzogia 15: 91-128.

Magnusson, A.H. 1947. Studies in non-saxicolous species of Rinodina mainly from Europe and Siberia. Acta Horti Gothoburgensis 17: 191-338.

Mayrhofer, H. \& R. Moberg. 2002. Rinodina. In: T. Ahti, P.M. Jørgensen, H. Kristinsson, R. Moberg, U. Søchting \& G. Thor (eds.), Nordic Lichen Flora. Vol. 2. Physciaceae. Nordic Lichen Society, Uddevalla, Sweden, pp. 41-69.

Mayrhofer, H., G. Kantvilas \& K. Ropin. 1999. The corticolous species of the lichen genus Rinodina (Physciaceae) in temperate Australia. Muelleria 12(2): 169-194.

Mayrhofer, H., M. Lambauer \& C. Edler. 2007. Rinodina. In: D.J. Galloway, Flora of New Zealand Lichens. Revised Second Edition Including Lichen-Forming and Lichenicolous Fungi, Volume 2. Manaaki Whenua Press, Lincoln, New Zealand, pp. 1563-1590.

Moreira-MuÑoz, A. 2011. Plant geography of Chile. Plant \&Vegetation Series, vol. 5. Springer Verlag, Germany, Berlin. i-xxi +343 pp.

Orange, A., P.W. James \& F.J. White. 2001. Microchemical methods for the identification of lichens. British Lichen Society. 101 pp.

Ropin, K. \& H. MaYrhofer. 1993. Zur Kenntnis corticoler Arten der Gattung Rinodina (lichenisierte Ascomyceten) in den Ostalpen und angrenzenden Gebieten. Herzogia 9: 779835.

Sheard, J.W. 2004. Rinodina. In: T.H. Nash III, B.D. Ryan, P. Diederich, C. Gries \& F. Bungartz (eds.), Lichen Flora of the Greater Sonoran Desert Region, Vol. 2. Lichens Unlimited, Arizona State University, Tempe, Arizona, pp. 467-502.

SHEARD, J.W. 2010. The lichen genus Rinodina (Lecanoromycetidae, Physciaceae) in North America, north of Mexico. NRC Research Press, Ottawa, Ontario, Canada. 246 pp.

Torres-Mura, J.C., S. Castro \& D. Oliva. 2008. Conservación de la Biodiversidad. En: CONAMA (ed.), Biodiversidad de Chile: patrimonio y desafíos, 2nd ed. CONAMA, Santiago, pp 413-431.

WIRTH, V. 1997. Additional lichen records from New Zealand. 21. Candelariella coralliza, Lepraria eburnea, Racodium rupestre, Rinodina olivaceobrunnea, Rinodina pyrina, and Trapeliopsis flexuosa. Australasian Lichenological Newsletter 40: 11-13.

Recibido: 19.02 .13

Aceptado: 09.08.13 